\title{
A Study on Corporate Social Responsibility and Environmental Disclosure of Kerala Solvent Extracts Ltd, (KSE) Irinjalakuda, Thrissur, Kerala.
}

\author{
Ms. Remya. S ${ }^{1}$, Dr G.S Sandhya Nair ${ }^{2}$ \\ ${ }^{1}$ Assistant Professor \& Research Scholar, St Joseph's College Autonomous, Irinjalakuda. \\ ${ }^{2}$ Assistant Professor \& Research Guide, Sree Vivekananda College, Kunnamkulam.
}

\begin{abstract}
The CSR policy of KSE Ltd incorporates the company's philosophy for giving back to the society as a corporate citizen and lays down the guidelines and mechanism for undertaking socially useful programs for the welfare and sustainable development of community at large. The main objective of the study is to identify the activities under CSR and how they are disclosed in the annual accounts of the company. An attempt has been made to know the amount spend on CSR activities. The study is done on the data provided by the company and the questionnaire collected from the company. For the success of CSR, the company has formed a CSR Committee that consists of a Chairman, one independent director, and two non-executive directors. The various factors that influence CSR and Environmental disclosure has been identified. A brief review on the attitude of stakeholders towards CSR and disclosure has also been analyzed.
\end{abstract}

Keywords: CSR, KSE, Chairman.

\section{INTRODUCTION}

The concept of corporate social responsibility means doing the right thing. Corporate Social Responsibility also called corporate conscience, corporate citizenship, or responsible business is a form of corporate self-regulation integrated into a business model. CSR policy functions as a self-regulatory mechanism whereby a business monitors and ensures its active compliance with the spirit of law, ethical standards and national or international norms. With the world of business being as competitive as ever, it is important to stand out from the crowd. Suppliers have to work harder to win the contracts. Therefore, developing a CSR policy is a way of demonstrating company's integrity that can only reflect well on the customers. In fact, some customers do not just prefer working with responsible companies. This is particularly prevalent in the public sector who are expected to set the standard. Reducing the amount of resources used and waste produced is not just beneficial for saving the environment. Engaging and giving back to community is a good way of earning positive press coverage. From sponsoring a charity event, to hiring staff locally, CSR efforts boosts reputation massively potentially leading more customers. Understanding the wider impact of business through initiatives like CSR can also help to develop new products or services. Environment includes all surroundings of a living organism. The relationship maintained by company and its stakeholders is not new. All organizations in both public and private sector have realized their importance to serve the shareholders. Now a day's shareholder is more concerned about the societal and environmental implications of business. Because of this, companies have started reporting on their societal and environmental performance apart from their financial performance. CSR reporting is a voluntary tool adopted by company to report both qualitative and quantitative information about the companies' environmental activities. CSR reporting is also essential to attain the goal of corporate sustainability. The Global Reporting Initiative has become one of the most important concerns of financial industry. A widespread CSR reporting standard is adopted internationally. The stakeholders are demanding for the periodic sustainability disclosure.

\section{LITERATURE REVIEW}

Jorge A Arevalo and Deepa Aravind (2011) concluded in their article entitled Corporate Social Responsibility practices in India approach, drivers and barriers that the CSR approach that is most favored by Indian firms is the stake holder approach and that the caring or moral motive followed by strategic or profit motive are important drivers for Indian firms 
Vol. 8, Issue 6, June 2021

DOI: $10.17148 /$ IARJSET.2021.8689

to pursue CSR. Further the results indicate that the most significant obstacles to CSR implementation are those related to lack of resources, followed by those related to complexity and difficulty of implementing.MC Gaw (2005) considers the biggest challenge in the field of CSR implementation is to be development of leaders for a sustainable global society and how they can develop best individuals with these leadership capabilities. According to him, the task and challenge will be to develop leaders for a sustainable global society by encouraging imagination and accomplishment of a positive change. Berkhout T (2005) critically examines corporate gains as a strategic engine for long-term corporate profits and reasonable social development. He highlights corporate green washing, the voluntary adoption of a token social or environmental initiative intended to enhance a company's corporate image. He points out that CSR provides the starting point that the businesses need to begin moving towards sustainability. For CSR to achieve its potential, companies must push to seek something other than lowest short-term cost for highest short-term gain.

\section{OBJECTIVES OF THE STUDY}

- $\quad$ To study the various CSR activities in KSE Ltd.

- To identify how the funds are utilized for the success of CSR.

- $\quad$ To know the factors that influence CSR activities of KSE Ltd.

- $\quad$ To study the attitude of stakeholders towards CSR and Corporate Environmental disclosure.

\section{RESEARCH METHODOLOGY}

Data required for the study are obtained through primary and secondary sources. The primary data has been collected with the help of well-structured online-circulated questionnaire from 50 respondents who were the employees and accountants of KSE Ltd. The secondary data has been collected from various books, journals, website etc. Financial statements and annual reports of the company was also analyzed. Descriptive method has been used for the for the purpose of the study. The convenience sampling method was used for the study. Percentage analysis, ranking and Likert scale has been used for the study.

\section{LIMITATIONS OF THE STUDY}

- $\quad$ The study is restricted to only a past few years

- $\quad$ The study is confined to only one company

\section{STATEMENT OF THE PROBLEM}

The concept of corporate social responsibility has gained prominence from all avenues. The organizations have realized that government alone will not be able to get success in its endeavor to uplift the underprivileged part of the society. With rapidly changing corporate environment, economy that is more functional, operational freedom etc. the company considers CSR as a strategic tool for sustainable growth.

\section{SIGNIFICANCE OF THE STUDY}

The firms disclose environmental information voluntarily in their annual reports and websites. They provide environmental performance information and influence capital markets. The foreign companies are very much concerned about the issues like reputation, expectations of the society; legal requirements etc. as motives that encourage them to disclose environmental information. It provides information on what firms have done for the sake of community.it also helps in determining what they have contributed to the welfare of the society and what they will do in the future for the welfare and interest of the society. CSR improves likeness of merchandise or business, company sales, Increase in profitability, improved competitive advantage as customers prefer environmentally amicable goods and services, Good scrounging access from the point of view of shareholders, bankers and creditors, Improvement in the well-being and safety of employees and Increase productivity of employees.

\section{SCOPE OF THE STUDY}

The study covers the employees and stakeholders of KSE Ltd, Irinjalakuda, and Thrissur district. The annual reports of the company for the past 5 years has also been analyzed to determine the amount of fund utilized for CSR activities and trend of Corporate Environmental disclosure.

\section{DISCUSSION AND FINDINGS}


International Advanced Research Journal in Science, Engineering and Technology

Vol. 8, Issue 6, June 2021

DOI: $10.17148 /$ IARJSET.2021.8689

Table 9.1 Demographic Profile of Respondents

\begin{tabular}{|c|c|c|c|}
\hline \multirow{2}{*}{ Factors } & Classification & No of Respondents & Percentage of Respondents \\
\hline \multirow{2}{*}{ Gender } & Male & 42 & 84 \\
\cline { 2 - 4 } & Female & 8 & 16 \\
\hline \multirow{2}{*}{ Age } & Below 30 & 5 & 10 \\
\cline { 2 - 4 } & $30-45$ & 20 & 40 \\
\cline { 2 - 4 } & $45-60$ & 25 & 50 \\
\hline \multirow{2}{*}{ Educational Qualification } & Graduation & 28 & 56 \\
\cline { 2 - 4 } & Post-Graduation & 10 & 20 \\
\cline { 2 - 4 } & Others & 12 & 24 \\
\hline
\end{tabular}

Table 9.2 Awareness of CSR as a Terminology

\begin{tabular}{|c|c|c|}
\hline Particulars & No of Respondents & Percentage of Respondents \\
\hline Aware & 48 & 96 \\
\hline Not Aware & 2 & 4 \\
\hline Total & 50 & 100 \\
\hline
\end{tabular}

Table 9.3 Clarification of Respondents about CSR

\begin{tabular}{|c|c|c|}
\hline Particulars & No of Respondents & Percentage of Respondents \\
\hline Very clear & 26 & 52 \\
\hline Somewhat clear & 18 & 36 \\
\hline Indifferent & 4 & 8 \\
\hline Not clear & 2 & 100 \\
\hline Total & 50 & 4 \\
\hline
\end{tabular}

Table 9.4 Relation between CSR and Profitability

\begin{tabular}{|c|c|c|}
\hline Particulars & No of Respondents & Percentage of Respondents \\
\hline Related & 48 & 96 \\
\hline Not related & 2 & 4 \\
\hline Total & 50 & 100 \\
\hline
\end{tabular}

Table 9.5 Strategy for CSR Implementation

\begin{tabular}{|c|c|c|}
\hline Particulars & No of Respondents & Percentage of Respondents \\
\hline CSR committee & 40 & 80 \\
\hline Non-commercial organisation & 0 & 0 \\
\hline Line department & 8 & 4 \\
\hline Foundation trust & 2 & 100 \\
\hline Total & 50 & \\
\hline
\end{tabular}

Table 9.6 Types of resources provided in the form of CSR

\begin{tabular}{|c|c|c|}
\hline Particulars & No of Respondents & Percentage of Respondents \\
\hline Money & 8 & 16 \\
\hline In kind & 32 & 64 \\
\hline
\end{tabular}


International Advanced Research Journal in Science, Engineering and Technology

Vol. 8, Issue 6, June 2021

DOI: $10.17148 / I A R J S E T .2021 .8689$

\begin{tabular}{|c|c|c|}
\hline Loans & 0 & 0 \\
\hline Others & 10 & 20 \\
\hline Total & 50 & 100 \\
\hline
\end{tabular}

Table 9.7 Community Investment Initiatives

\begin{tabular}{|c|c|c|c|}
\hline Community investment Initiatives & Classification & No of Respondents & Percentage of Respondents \\
\hline \multirow[t]{2}{*}{ Promotion of health care } & Yes & 48 & 96 \\
\hline & No & 2 & 4 \\
\hline \multirow[t]{2}{*}{ Conservation of natural resources } & Yes & 38 & 76 \\
\hline & No & 12 & 24 \\
\hline \multirow{2}{*}{$\begin{array}{c}\text { Promotion of education and } \\
\text { employment }\end{array}$} & Yes & 50 & 100 \\
\hline & No & 0 & 0 \\
\hline \multirow[t]{2}{*}{ Local heritage } & Yes & 20 & 40 \\
\hline & No & 30 & 60 \\
\hline \multirow{2}{*}{$\begin{array}{c}\text { Promotion of setting up of old age } \\
\text { homes }\end{array}$} & Yes & 42 & 84 \\
\hline & No & 8 & 16 \\
\hline \multirow{3}{*}{$\begin{array}{l}\text { Promotion of special education for } \\
\text { differently abled }\end{array}$} & & & \\
\hline & Yes & 45 & 90 \\
\hline & No & 5 & 10 \\
\hline \multirow[t]{2}{*}{ Poverty alleviation } & Yes & 0 & 0 \\
\hline & No & 50 & 100 \\
\hline \multirow[t]{2}{*}{ Promotion of sanitation } & Yes & 30 & 60 \\
\hline & No & 20 & 40 \\
\hline
\end{tabular}

Table 9.8 Key beneficiaries of CSR Activities

\begin{tabular}{|c|c|c|}
\hline Particulars & No of Respondents & Percentage of Respondents \\
\hline Environment & 4 & 8 \\
\hline Women & 3 & 30 \\
\hline Children & 15 & 20 \\
\hline Disabled & 10 & 36 \\
\hline Others & 18 & 6 \\
\hline
\end{tabular}

Table 9.9 Meetings held by CSR Committee

\begin{tabular}{|c|c|c|}
\hline Particulars & No of Respondents & Percentage of Respondents \\
\hline Monthly & 2 & 4 \\
\hline Quarterly & 40 & 80 \\
\hline Half yearly & 6 & 12 \\
\hline Yearly & 2 & 4 \\
\hline
\end{tabular}

Table 9.10 Amount utilized in CSR activities in Lakhs

\begin{tabular}{|c|c|c|c|}
\hline Activities identified & Amount 2019-20 & $2018-19$ & $2017-18$ \\
\hline Promotion of health care & 51.16 & 26.25 & 15.35 \\
\hline $\begin{array}{c}\text { Promotion of education \& } \\
\text { employment }\end{array}$ & 2.06 & 1.04 & - \\
\hline
\end{tabular}


International Advanced Research Journal in Science, Engineering and Technology

Vol. 8, Issue 6, June 2021

DOI: $10.17148 / I A R J S E T .2021 .8689$

\begin{tabular}{|c|c|c|c|}
\hline $\begin{array}{c}\text { Promotion of special } \\
\text { education for differently } \\
\text { abled }\end{array}$ & 2.80 & 14.53 & - \\
\hline $\begin{array}{c}\text { Promotion of setting up of } \\
\text { old age homes }\end{array}$ & 0.75 & 4.72 & - \\
\hline Promotion of sanitation & 2.78 & - & 15.5 \\
\hline $\begin{array}{c}\text { Conservation of natural } \\
\text { resources }\end{array}$ & - & 9.29 & - \\
\hline
\end{tabular}

Table 9.11 Drivers of CSR

\begin{tabular}{|c|c|c|c|c|c|c|c|c|c|c|c|}
\hline Drivers of CSR & Weight & 7 & 6 & 5 & 4 & 3 & 2 & 1 & Total & Mean & Rank \\
\hline \multirow[t]{2}{*}{ Image building } & $\mathrm{F}$ & 14 & 15 & 4 & 8 & 4 & 5 & 0 & 50 & \multirow[t]{2}{*}{5.24} & \multirow[t]{2}{*}{2} \\
\hline & FX & 98 & 90 & 20 & 32 & 12 & 10 & 0 & 262 & & \\
\hline \multirow[t]{2}{*}{ Increase in profits } & $\mathrm{F}$ & 7 & 8 & 7 & 10 & 8 & 7 & 3 & 50 & \multirow[t]{2}{*}{4.26} & \multirow[t]{2}{*}{3} \\
\hline & FX & 49 & 48 & 35 & 40 & 24 & 14 & 3 & 213 & & \\
\hline \multirow[t]{2}{*}{ Legal compliance } & $\mathrm{F}$ & 21 & 11 & 3 & 11 & 2 & 0 & 2 & 50 & \multirow[t]{2}{*}{5.6} & \multirow[t]{2}{*}{1} \\
\hline & $\mathrm{FX}$ & 147 & 66 & 15 & 44 & 6 & 0 & 2 & 280 & & \\
\hline \multirow[t]{2}{*}{ Risk mitigation } & $\mathrm{F}$ & 1 & 3 & 8 & 5 & 8 & 14 & 11 & 50 & \multirow[t]{2}{*}{2.96} & \multirow[t]{2}{*}{6} \\
\hline & FX & 7 & 18 & 40 & 20 & 24 & 28 & 11 & 148 & & \\
\hline \multirow[t]{2}{*}{ Shared value } & $\mathrm{F}$ & 2 & 8 & 18 & 5 & 11 & 1 & 5 & 50 & \multirow[t]{2}{*}{4.24} & \multirow[t]{2}{*}{4} \\
\hline & FX & 14 & 48 & 90 & 20 & 33 & 2 & 5 & 212 & & \\
\hline \multirow{2}{*}{$\begin{array}{l}\text { Social good } \\
\text { compliance }\end{array}$} & $\mathrm{F}$ & 1 & 0 & 6 & 11 & 14 & 14 & 4 & 50 & \multirow[t]{2}{*}{3.1} & \multirow[t]{2}{*}{5} \\
\hline & FX & 7 & 0 & 30 & 44 & 42 & 28 & 4 & 155 & & \\
\hline \multirow[t]{2}{*}{ Employee satisfaction } & $\mathrm{F}$ & 4 & 5 & 4 & 0 & 3 & 9 & 25 & 50 & \multirow[t]{2}{*}{2.6} & \multirow[t]{2}{*}{7} \\
\hline & $\mathrm{FX}$ & 28 & 30 & 20 & 0 & 9 & 18 & 25 & 130 & & \\
\hline
\end{tabular}

- $\quad 25$ respondents are in the age group of 45-60 years, 20 respondents were in the age group of 30-45 years and only 5 respondents were in the age group of below 30 years

- $\quad 42$ respondents were male and only 8 respondents were female

- $\quad$ Out of 50 respondents, 28 were graduates, 10 were postgraduates and 12 have other diplomas

- $\quad$ Around 96 percent of respondents were aware of CSR terminology and only 4 percent were not aware

- $\quad$ Around 52 percent of respondents have very clear idea about CSR,36 percent have somewhat clear idea about CSR , 8 percent were indifferent and only 4 percent do not have clear idea about CSR

- $\quad 96$ percent of the respondents have the opinion that there was positive relationship between CSR and profitability and 4 percent opposed to the fact

- $\quad 80$ percent of the respondents argue that CSR is implemented through CSR committee,16 percent said that CSR implemented through line department and 4 percent said that it is implemented through foundation trust

- 16 percent of the respondents opined that money is provided in the form of CSR,64 percent were of the opinion that it was not provided in the form of money,20 percent opined that construction, renovations etc. were provided in the form of CSR 


\section{International Advanced Research Journal in Science, Engineering and Technology}

Vol. 8, Issue 6, June 2021

DOI: $10.17148 /$ IARJSET.2021.8689

- 96 percent of the respondents were of the opinion that the company is doing activities for the promotion of health care

- $\quad 76$ percent of the respondents opined that the company is involved in conservation of natural resources

- All respondents were of the opinion that the company is involved in promotion of education and employment

- $\quad$ Only 40 percent of the respondents opined that the company invested in local heritage

- $\quad$ Around 84 percent of respondents opined that the company is involved in the promotion of setting up of old age homes

- $\quad$ Around 90 percent of the respondents opined that the company is involved in promotion of special education for differently abled

- $\quad$ Majority of the respondents were of the opinion that the company has not been doing poverty alleviation

- 30 percent of respondents said that they are doing activities for the promotion of sanitation

- 8 percent of the respondents argue that environment is the key beneficiary of CSR,6 percent argued that woman is the key beneficiary, 30 percent opined that children is the key beneficiary and 20 percent opined that Disabled persons were the key beneficiary of CSR

- $\quad$ Majority of CSR meetings were conducted quarterly and monthly and yearly meetings were conducted very rarely

of sanitation

- $\quad$ The most influencing factor of CSR is legal compliance, the next was image building, then increase in profits, then shared value and social good compliance was the next factor. The least influencing factor were Risk mitigation and employee satisfaction

\section{SUGGESTIONS}

- $\quad$ The company should do more activities under CSR such as poverty alleviation programs, local heritage, youth development etc.

- $\quad$ The company should try to contribute to the fund set up by central or state government for socio economic development, and funds for welfare of scheduled castes, scheduled tribes, other backward classes, minorities and women - The company should actively work to create an environment that encourages employees to come forward with ideas about how to improve CSR.

\section{CONCLUSION}

The main objective of CSR policy of KSE ltd is to establish general framework of action for management to undertake and fulfil its corporate social responsibility. The company always spend above the prescribed CSR expenditure that is above 2 percent of the average net profit for the three immediately preceding financial year. The company spent more for promotion of health care and least for local heritage. The ranking analysis reveals that the most influencing factor of CSR is legal compliance it takes 20 years to build a reputation and only 5 minutes to ruin it. Business should not only be responsible morally to stakeholders but also towards society and environment at large. The major development goals at the heart of CSR are eradicate extreme poverty and hunger, achieve universal primary education, promote gender equality and empower woman, reduce child mortality, improve maternal health and ensure environment sustainability. Thus, CSR helps to improve public image, increase media coverage, boosts employee engagement, attracts, and retains investors. The main benefits to employees include positive workplace environment, increase in creativity, encourage professional and personal growth and promote individual philanthropy.

\section{REFERENCES}

[1]. Remya S. "Covid19 and Environment-A Theoretical Review from Higher Education Students Perspective". International Research Journal on Advanced Science Hub, 2, Special Issue ICARD 2020, 2020, 227-230. doi: 10.47392/irjash.2020.124

[2].Jorge A Arevalo and Deepa Aravind 2011, CSR practices in India: approach, drivers and barriers-Corporate Governance-Volume 11 -Issue number 4-March 2011.

[3]. Indu Jain (2008) CSR practices in India, Time group, New Delhi-Volume 5-issue number 2 November 2008.

[4].Malini M (2015) CSR in emerging economies -Journal of corporate citizenship-volume 24-issue number 20.

[5].M.C Gaw(2014) Integrating sustainability into management education-a status report-International journal of advanced research -volume 2-issue number 11 . 